\title{
Vasoproliferative Retinopathies: Clinical, Morphogenetic and Modulatory Aspects
}

\author{
M E BOULTON, ${ }^{1}$ D McLEOD ${ }^{2}$ and A GARNER ${ }^{3}$ \\ London
}

In 1948, the year of inception of the Institute of Ophthalmology, Isaac Michaelson presented his now classic paper on retinal neovascularisation to the Ophthalmological Society of the United Kingdom. ${ }^{1}$ In it he postulated the existence and role of a biochemical factor of extravascular retinal origin which promotes the growth of capillary blood vessels in both the fetal development of the retinal circulation and preretinally in such pathological conditions as Eales' Disease, proliferative diabetic retinopathy (PDR) and after retinal vein occlusion (RVO), Subsequent events have served to support Michaelson's basic hypothesis, although it was not until the early 1980s that the existence of an angiogenic factor in the retina was convincingly demonstrated and still its precise nature and origin is unknown.

This review will focus particularly on advances in knowledge of neovascular morphogenesis, the role of angiogenic factors occurring in the retina, the retinal pigment epithelium (RPE) and the vitreous, and will consider the clinical implications of Michaelson's ideas. This will reflect improved laboratory and clinical investigational methods and the opportunities to influence vasoproliferative retinopathies (VPRs) clinically by retinal photocoagulation and vitrectomy.

\section{(I) Clinical Considerations}

The Retinal Metabolic Defect

Michaelson $^{1}$ suggested that preretinal neovascularisation reflected a disturbance in metabolism due to an insufficiency or complete occlusion of retinal circulation. However, it was Ashton's Indian ink injection studies of postmortem diabetic eyes ${ }^{2}$ which first specifically demonstrated the relationship between VPRs and retinal capillary non-perfusion (wherein the capillaries remained as basement membrane tubes eventually invaded by glia). Ashton ${ }^{3}$ went on to show that the neovascularisation of PDR and that following central RVO was invariably associated with such underlying areas of obliterated retinal capillaries, and that the neovascular response was proportionate to the extent of persistent vaso-obliteration. ${ }^{4}$ These concepts were confirmed in a wider clinical context with the advent of fluorescein angiography including the demonstration of a quantitative relationship between the area of capillary non-perfusion and the development of neovascularisation after branch $\mathrm{RVO}^{5,6}$ and in PDR. ${ }^{7,8}$ This quantitative relationship lends support to Michaelson's original hypothesis.

The delay period of weeks or months between the onset of inner retinal ischaemia (say after branch RVO) and the development of clinicallymanifest neovascularisation, together with the commonly slow progression of neovascularisation thereafter over weeks or months, suggests that tissue necrosis per se is unlikely to be responsible for the angiogenic stimulation. Metabolic exchange with the vitreous or via the outer retina may mitigate the effects of retinal

From Departments of Clinical Ophthamology ${ }^{1}$ and Pathology, ${ }^{3}$ Institute of Ophthalmology and Surgical Vitreoretinal Unit, Moorfields Eye Hospital ${ }^{2}$

Correspondence to: Dr M E Boulton, Dept of Clinical Ophthalmology, Institute of Ophthalmology, Judd Street, London WC1H 9QS. 
capillary non-perfusion on the inner retina, and it is widely held ${ }^{4,9,10,11}$ that the angiogenic factor is derived from hypoxic (rather than anoxic) retinal tissue. This concept is supported by the disappearance of neovascularisation in pulseless disease after surgical restoration of the carotid arterial supply. ${ }^{12}$ The lack of a neovascular response to retinal arterial occlusion (RAOs), whether central or branch RAO, has also been explained on a similar basis $i e$ the affected retina is allegedly anoxic as opposed to merely hypoxic after RVO. However, there is no difference between the haemorrhagic infarction or RVO and the "white infarct" of RAO in respect of the resulting visual functional deficit or the ischaemic obstruction of axoplasmic transport visible ophthalmoscopically in the retinal nervefibre layer. ${ }^{13}$ Rather, the absence of neovascularisation probably reflects the fact that RAOs are usually transient. Thus, re-perfusion of the capillary bed of the necrotic inner retina would "wash out" any angiogenic factors into the general circulation, and, teleologically, no neovascularisation would be required.

\section{The Extraretinal Neovascular Response}

Michaelson' demonstrated both clinically and histopathologically that preretinal neovascularisation arises from intraretinal venules, a concept confirmed many times over. However, pre-capillary new vessels sometimes have their origin from the posterior ciliary circulation and occasionally preretinal neovascularisation may have a choroidal origin via a chorio-retinal scar.

The proximity of preretinal neovascularisation to the associated area of capillary non-perfusion and the directionality of the neovascular proliferation towards the under-perfused retina are both in keeping with Michaelson's hypothesis of an angiogenic factor. That new vessels arise immediately adjacent to an area of vasoobliteration was first shown in experimental $\mathrm{ROP}^{4}$ but is equally true for sickle-cell disease, RVO and FDR (Fig 1). An alternative or complimentary explanation for the proximity of neovascularisation to areas of retinal capillary non-perfusion is that the responding vessels must be altered or "conditioned" in some way by the original ischaemic episode. ${ }^{11,14}$ However, the capability of vessels distant from a discrete area of non-perfusion also to develop new vessels ${ }^{15}$ suggests at the very least that conditioning of the retinal vasculature is not obligatory for neovascularisation.

The development of preretinal neovascularisation remote from the abnormal retina $e g$ at the optic disc or elsewhere in the retina, also lends credence to Michaelson's hypothesis of a diffusible factor. In PDR, the development of disc neovascularisation has a quantitative implication indicating very extensive areas of capillary nonperfusion. ${ }^{8}$ However, the development of disc neovascularisation without new vessels elsewhere on the retina is not so readily explained. Henkind $^{11}$ speculated that the disc vasculature has an enhanced susceptibility to angiogenic factors compared with the retinal vessels. If so, this might possibly reflect the presence of primary hyaloid remnants (both vascular as well as glial) on the disc, or localised attenuation of the inner limiting lamina (ILL) over the disc.

Michaelson postulated that distant neovascularisation on the iris reflects the diffusion of angiogenic factors into the anterior chamber from the posterior part of the globe. ${ }^{1}$ Again, a quantitative relationship between rubeosis and the area of retinal capillary non-perfusion has subsequently been demonstrated in PDR. ${ }^{8}$ Furthermore, rubeosis is very frequent after ischaemic central $\mathrm{RVO}^{16}$ but is seldom seen after branch RVO.

\section{Intraocular Diffusion of Angiogenic Factors}

Ashton $^{4}$ suggested that the angiogenic factor from hypoxic retina "seeps into the vitreous" where it reaches a concentration sufficient to stimulate inward growth of new vessels. The hyaluronic acid component of the vitreous gel is probably important in impeding the diffusion of angiogenic factor and thus in maintaining a high concentration immediately preretinally. ${ }^{17}$ It has also been reported that the vitreous gel contains an inhibitor of neovascularisation (for review see Garner $)^{18}$ perhaps similar to that held responsible for the regression of the primary hyaloid vascular system in-utero. The role of the vitreous as a diffusion barrier to angiogenic factors (rather than a source of anti-angiogenic activity) is illustrated by the effect of vitrectomy in PDR. Any residual fibroviascular tissue on the retina after vitrectomy undergoes involution or regression of its vascular component, ${ }^{19,20}$ implying that the gel is normally important in localising 


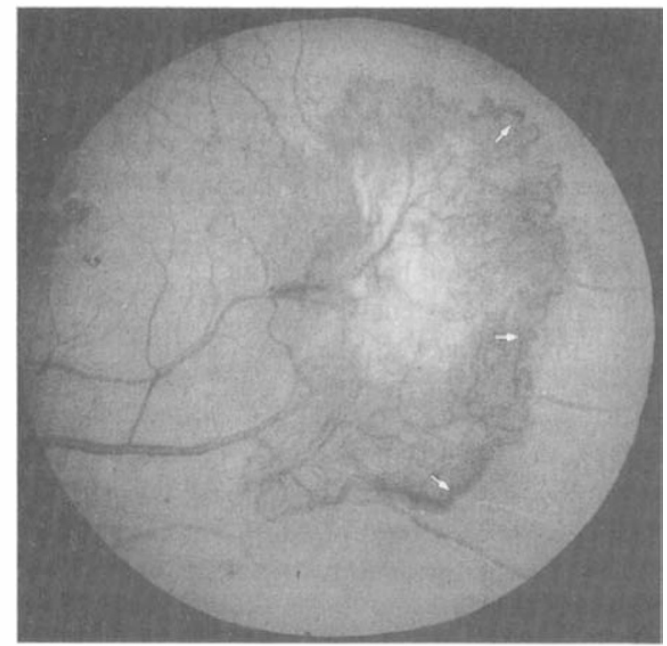

Fig. 1. Diabetic fibrovascular epiretinal membrane inferotemporal to left macula illustrating proximity and directional (arrows) of new vessels in relation to midperipheral inner retinal ischaemia.

angiogenic factors in proximity to the retina. More anteriorly, however, post-operative neovascularisation may arise in the vitreous base and on residual anterior vitreous in phakic eyes ("retrolental neovascularisation") $)^{21}$ or on the iris, especially if the eye is aphakic. ${ }^{22}$

As well as forming a barrier to diffusion of angiogenic factors and possessing antiangiogenic activity, clinical observations suggest that the vitreous also has an important role as a scaffold or substrate for preretinal neovascularisation. This is suggested firstly by the spread of neovascularisation in the same plane as the retinal surface (but within the lamellae of cortical vitreous collagen) to form vascularised epiretinal membranes (Fig 1). The possible role of the vitreous as a substrate is suggested secondly by the effect of prior posterior vitreous detachment (PVD) in protecting the retina from preretinal neovascularisation. ${ }^{23}$ This is not to deny any preretinal neovascularisation after PVD. In ischaemic diabetic retinopathy, and indeed in other such retinopathies, "abortive" neovascular outgrowths from the surface of the retina may be observed behind the detached vitreous face. ${ }^{24}$ Abortive neovascular outgrowths comprise discrete spherical neovascular lesions typically located in the zone bordering areas of capillary non-perfusion and showing all the usual features of pre-retinal neovasculari- sation except for extension of neovascular processes over the retinal surface from their site of outgrowth from the retina (Fig 2). Localised prepapillary neovascularisation may also develop despite prior PVD. ${ }^{24}$

\section{Interplay of Clinical and Surgical Influences}

While the progressive quantitative relationship between the area of capillary non-perfusion and the development of preretinal, prepapillary and iris neovascularisation respectively is in keeping with Michaelson's hypothesis, exceptions to this trend are also seen, for example in PDR and after central RVO. Thus, diabetic patients may present with rubeosis iridis complicating severe retinal ischaemia but without any preretinal neovascularisation. Such patients usually have a complete PVD thus illustrating the role of the vitreous gel in providing a substrate for epiretinal vaso-proliferation. Similarly, after ischaemic central RVO, the principal clinical manifestation of neovascularisation is rubeosis iridis rather than VPR. Chan and Little ${ }^{25}$ considered that this reflects the complete destruction of any potentially "reactive" retinal vascular

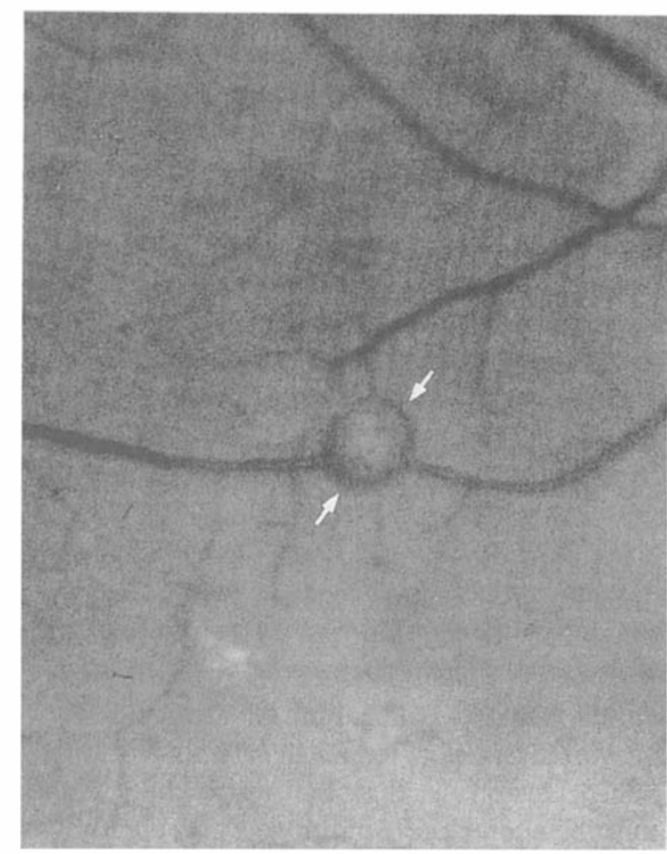

Fig. 2. Abortive neovascular outgrowth (between arrows) overlying an arteriole and arising from $a$ venule superotemporal to right macula in a diabetic with complete posterior vitreous detachment. 
endothelium following central RVO, but the paradox of rubeosis without VPR could equally be explained by associated PVD or other mechanisms, for example secondary sclerosis throughout the venous tree following the retrolaminar RVO. A similar apparent paradox arises from observations of eyes with ischaemic retinopathy, PVD and abortive neovascular outgrowths. Such eyes appear to be relatively protected from rubeosis iridis, implying that the detached vitreous imposes a barrier to anterior diffusion of angiogenic factors (thus preventing rubeosis) while maintaining a sufficient concentration of angiogenic factors in the retrohyaloid compartment to stimulate preretinal neovascularisation, albeit in an arrested form.

The relationship between vaso-proliferation and retinal detachment also provides some interesting examples of the interplay of clinical influences. Although detachment of immature feline retina resulted in preretinal (and subretinal) neovascularisation, ${ }^{26}$ detachment of the mature (cat) retina was not associated with secondary neovascularisation. In retinal detachments in clinical practice, however, occasional examples of neovascularisation in the peripheral vitreous base are indeed seen following very chronic retinal detachment, and rubeosis iridis is a frequent sequel to severe proliferative vitreoretinopathy. In PDR, the onset of traction retinal detachment may precipitate the development of rubeosis iridis (presumably by increasing the production of angiogenic factors) and retinal detachment in an aphakic vitrectomised diabetic eye is invariably complicated by rubeosis iridis. ${ }^{20}$ Reversal of rubeosis in each of these instances may result from reattachment of the retina per se (presumably by reducing the production of angiogenic factors).

Replacement of the vitreous gel by silicone oil has both predictable and paradoxical effects on neovascularisation in PDR. ${ }^{27}$ The reimposition of a barrier to diffusion of angiogenic factors away from the retina appears to be the basis for retrosilicone oil neovascularisation (Fig 3). ${ }^{21,28,29}$ The consequences for iris neovascularisation are variable, but intravitreal silicone oil appears to be protective against rubeosis if the retina remains detached ${ }^{27}$ (presumably by the diffusion barrier mechanism), while offering little or no protection from (or indeed apparently exacerbating) rubeosis in some instances if the

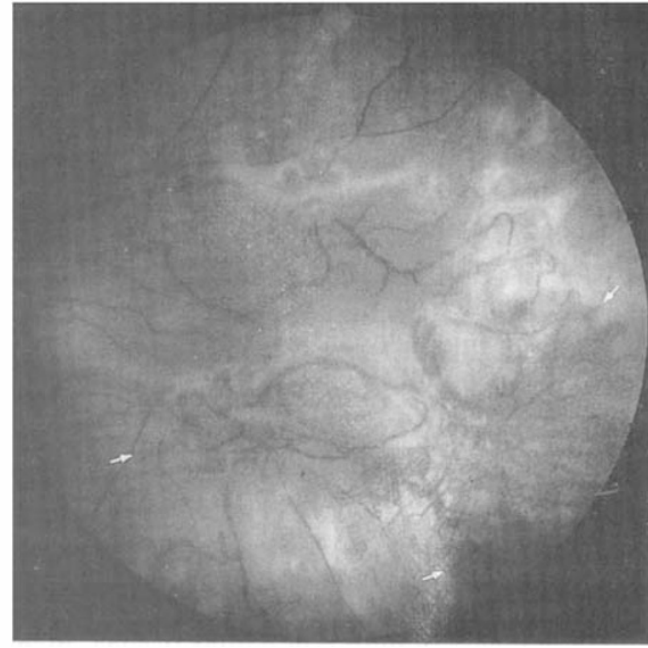

Fig. 3. Reproliferation of vascularised membranes (arrows) after complete vitrectomy, removal of all fibrovascular membranes and injection of silicone oil for diabetic traction detachment.

ischaemic retina is attached. ${ }^{27}$

Controlled clinical studies have demonstrated the efficacy of scatter photocoagulation in preventing or reversing retinal neovascularisation in $\mathrm{PDR},{ }^{30,31}$ branch $\mathrm{RVO}^{32}$ and for rubeosis complicating ischaemic central RVO. ${ }^{35}$ Scatter endophotocoagulation during vitrectomy for PDR also reduces the risk of post-operative retrolenticular neovascularisation, iris neovascularisation $^{34}$ and retrosilicone oil neovascularisation. ${ }^{29}$ How scatter photocoagulation exerts its beneficial effects on preretinal neovascularisation is unknown, but there are several theories. There may be a reduction in production of angiogenic factors either directly (by destruction of their retinal source) or indirectly by approximation of the inner retina to the choroid following photocoagulation, and improvement in oxygenation. ${ }^{35}$ Alternatively, photocoagulation may increase the egress of angiogenic factors into the choroid via the $\mathrm{RPE}^{36}$ or may stimulate production of an inhibitor of neovascularisation. 37,38

\section{Morphogenesis}

Initial events in the parent vessel

Dilatation of the parent vessel, which is usually a vein, commonly precedes neovascularisation and, by analogy with observations in experi- 
mental situations such as the rabbit ear and hamster cheek pouch, ${ }^{39,40}$ this appears to involve a functional dilatation as well as increased bulk of the endothelial lining. The endothelial cell swelling incurs an increase in intracytoplasmic organelles as an index of enhanced metabolic activity and, in vessels in other parts of the body including the choroid, ${ }^{41}$ is accompanied by a reduction and eventual absence of intercellular junctions. The corresponding stage with respect to the retina has yet to be described in detail and it is uncertain to what extent the much firmer tight junctions of the retinal circulation undergo an equivalent dissolution.

\section{Basement membrane lysis}

Again by analogy with non-ocular tissues, blebs form on the abluminal side of the activated endothelial cells and these extend through newly formed gaps in the vascular basement membrane. Such penetration appears to be integral to vasoproliferation and is probably facilitated by localised enzymatic lysis. In part, the degrading of the basement membrane collagen may be due to plasminogen activation such that the plasmin product further activates latent collagenases. ${ }^{42}$ Both the plasminogen activator and the procollagenase are produced directly by the vascular endothelial cells and their synthesis can be stimulated in tissue culture by exposure of the cells to crude retinal extracts. ${ }^{42}$ The retinal component responsible for initiating the collagenolytic system is uncertain but there is evidence implicating the release of a small molecule (approx 300-400 Da) shown to be present in the retinae of several animal species ${ }^{43}$ (and also in the vitreous of patients with PDR). ${ }^{44}$ The same substance can also stimulate proliferative and migratory activity on the part of the endothelium and has been designated endothelial cell stimulating angiogenesis factor (ESAF).$^{45}$ ESAF is a potent activator of latent procollagenase and, whilst it is most efficient in the presence of heparin, it can function in its absence. ${ }^{46}$ Vascular endothelium can also form a collagenase specific for the type IV collagen of basement membrane. ${ }^{47}$

\section{Endothelial cell migration and proliferation}

As the activated endothelium herniates through the basement membrane a bleb is formed which soon develops into a bud as adjacent cells, freed by disappearance of their intercellular junctions, slide over the bleb on the abluminal side to become the leading tip of the nascent vessel. ${ }^{48}$ Subsequently the cells proximal to the tip undergo mitotic division and these, in turn, migrate in a 'leap frog' fashion to form a new tip. Thus for angiogenesis to occur both migration and proliferation are needed.

\section{Lumen formation}

For the initially solid bud to become a new vessel a lumen has to develop and there is some controversy as to how this occurs. One mechanism postulated on the basis of in vitro culture of vascular endothelium is that the cells curl up and form junctions as the opposing tips of cells come into contact. ${ }^{49}$ As documented, however, this model presents a conceptual difficulty in that the curling appears to be such as to culminate in a basement membrane situated on the inner surface of the new vessel. ${ }^{49} \mathrm{~A}$ variation of this mode of lumen formation involves the use of a 'sacrificial' endothelial cell which acts as a focus for the migrating cells to surround: subsequent degeneration of the sacrificial cell and the formation of junctional complexes between the encircling cells gives rise to a central lumen. ${ }^{50}$ The relevance of this scheme, observed in tissue culture, to in vivo development remains to be seen. One method which has been observed in vivo presumes that the primary bleb consists of two (or more) contiguous cells which begin to separate at their proximal borders to form a lumen continuous with that of the parent vessel. ${ }^{51}$

\section{Emergence from the retina}

Since the vessels of the retina are confined to its inner layers and because many of the parent vessels are veins which lie almost adjacent to the surface, the new vessels proliferating towards the vitreous do not have far to go before meeting an obstruction in the form of the ILL. By virtue, in all probability, of collagenolytic mechanisms comparable to those responsible for the initial breaching of the vascular basement membrane, the newly formed capillary bud is able to penetrate this potential barrier. That this is a fairly specific capacity is suggested by a study of spontaneously hypertensive rats in which a VPR is accompanied by migration of RPE cells to the 
inner retina: ${ }^{52}$ whereas the new vessels cross the ILL with ease, the pigment epithelium is held back, possibly because such cells lack the appropriate enzymes or enzyme-activating potential. The precise nature of the collagenolytic enzymes remains to be shown, although Glaser ${ }^{53}$ states that the endothelium of developing blood vessels can activate tissue plasminogen which has the capacity to digest all the elements of basement membrane by virtue of a urokinase type of activator functioning in the absence of fibrin. It is also possible that such collagenolytic activity is triggered by the stimulus to angiogenesis itself, as proposed in the context of the initial bleb formation. ${ }^{46,47}$ Enzymatic activity of this type can also be expected to enable the vessels to spread over the surface of the ILL within the condensed collagen fibres that constitute the posterior hyaloid membrane. It is not necessary to postulate focal thinning of the ILL

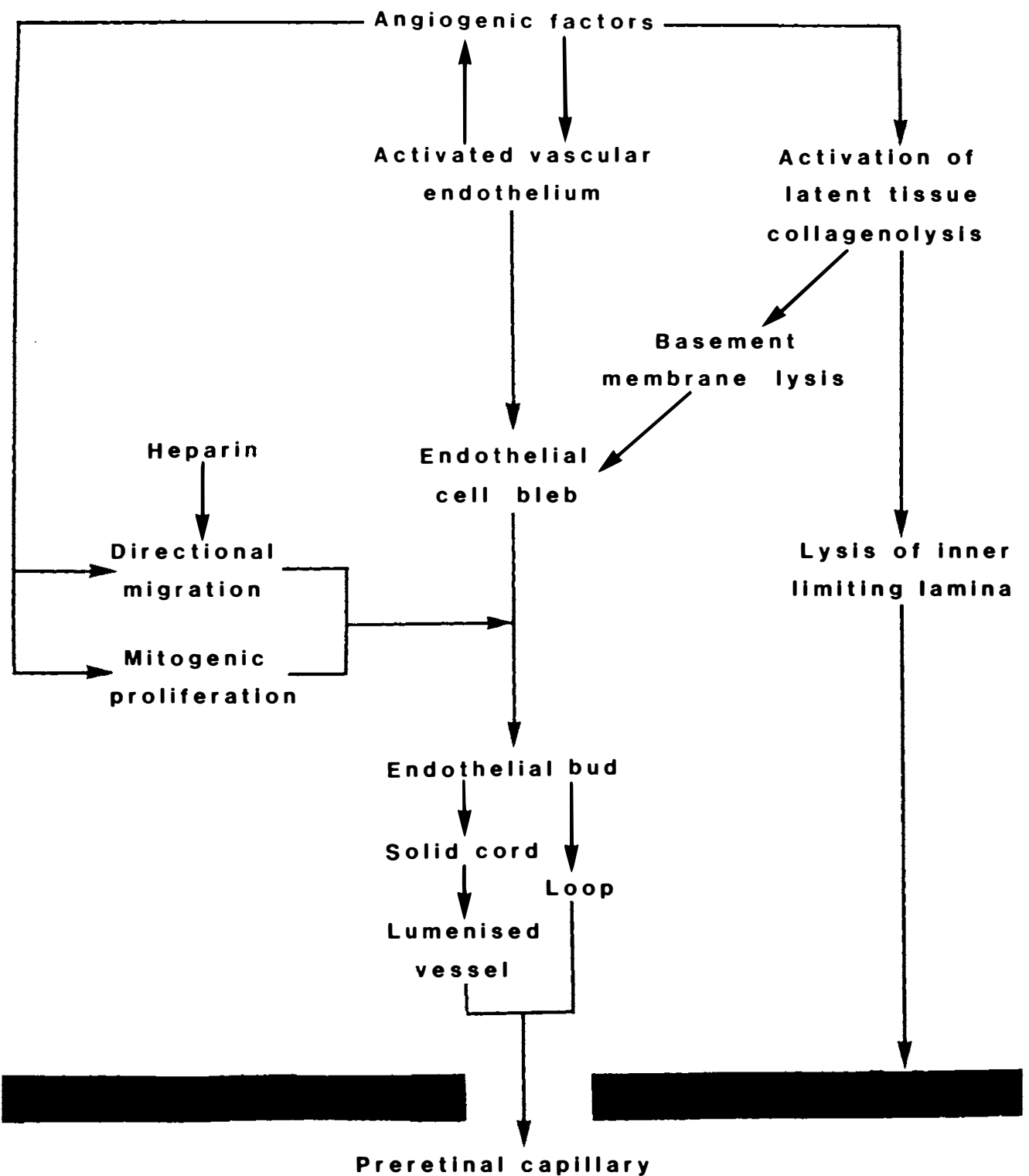

Fig. 4. Schematic representation of the initial development of new blood vessels prior to their penetration of the inner limiting lamina of the retina. 
as a prerequisite for preretinal vascular invasion unless it is seen as a reflection of collagenolytic activity. It is also difficult to reconcile the hypothesis that attenuation of the ILL must precede preretinal angiogenesis with the thickening of this membrane and increase in constituent proteins reported in patients with diabetic VPR. ${ }^{54}$ The sequence of events occurring in the initial phases of proliferative retinopathy are summarised in Figure 4.

\section{Preretinal vasoproliferation}

Archer ${ }^{14}$ in a detailed study of proliferative retinopathy in primates showed that the capillaries entering the preretinal space were in the shape of delicate loops but the mechanism of their formation is obscure and the same is probably true of the human retina (Fig 5). It is possible that, as has been claimed in respect of capillaries in other tissues, ${ }^{39}$ adjacent newlyformed vascular columns come into contact near their tips and fuse to create a loop. A further possibility is that in situ proliferation of endothelium occurs within a vessel resulting in elongation and subsequent kinking of the affected segment: a similar process has been proposed in respect of microaneurysm formation in diabetic retinopathy. ${ }^{55,56}$

It may be questioned as to why the new capillaries enter the preretinal zone in preference to proliferating within the retina. After all if it is reasoned, as Michaelson ${ }^{1}$ and others have done, that the stimulus to neovascularisation is the metabolic deprivation of the retinal tissue this would be the expected site of maximum angio-

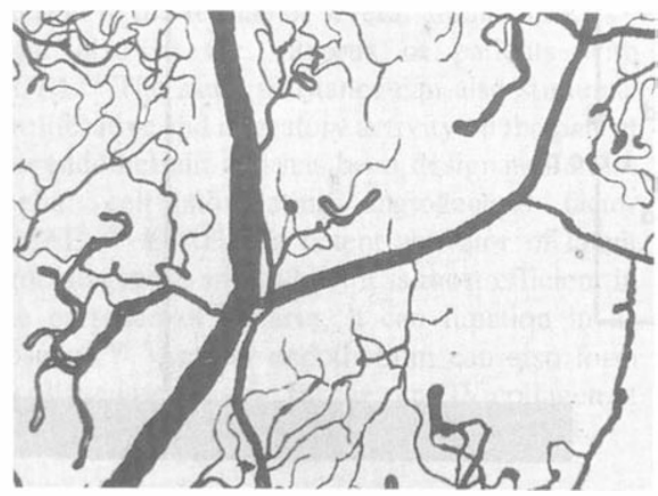

Fig. 5. Flat preparation of retina from a patient with proliferative diabetic retinopathy showing new vessels in the form of fine loops (Indian ink injection, $x$ 85). genesis. Undoubtedly, a measure of intraretinal angiogenesis can occur, as several investigators have shown, ${ }^{57}$ but, other than in experimentally induced hyperoxic retinopathy in kittens, ${ }^{58}$ is usually very limited. Ashton ${ }^{4}$ drew attention to the importance of poor drainage in allowing sufficient angiogenic factor to accumulate in the tissues for an effect to be produced. It could be, that the newly formed capillary buds turn to the vitreous because it is there that the highest concentration of angiogenic stimulants is to be found, given the limited drainage facility.

Initially, at least, the extraretinal angiogenesis is along the surface of the inner limiting membrane where further budding leads to a congerie of interconnecting capillaries. Sometimes, especially in ROP but also in respect of new vessels growing over the optic disc in PDR and central RVO, histological preparations reveal a zone of apparently dissociated cells in front of the definitive new capillaries. ${ }^{59,60}$ The nature of these cells is uncertain, although they are commonly spindle-shaped and are richly endowed with glycogen ${ }^{61}$ and, as such, resemble the presumed mesenchymal cells that precede the advancing edge of the normal intraretinal circulation in utero. ${ }^{62}$ It may be that these cells are the precursors of differentiated vascular endothelium, ${ }^{63,64}$ in which case it would be necessary to postulate a form of angiogenesis which differs from the budding process in allowing for the formation of vessels from primitive endothelium in a way that is comparable to that apparently pertaining in tissue culture systems. ${ }^{49,53,59}$ Alternatively the wave of glycogen-rich cells may provide a supportive role as an energy source for the budding vessels. ${ }^{65}$ Yet again, it has been suggested that the spindle-shaped cells are of glial derivation ${ }^{65}$ with specific implication of the Müller cells. ${ }^{66}$ Finally, by analogy with the spindle cell vanguard described in normal retinal angiogenesis and in $\mathrm{ROP},{ }^{67}$ it is conceivable that they are a source of angiogenic factor. ${ }^{68}$

The new vessels need a substrate on which to grow, it having been observed that proliferation in response to an ESAF as described by Elstow et $\mathrm{al}^{69}$ will not occur in the absence of collagen. The presence of a collagenous substrate may also be a factor in the capacity to form a lumen ${ }^{70,71}$ and on pericyte differentiation. ${ }^{72}$ In part the effect of the collagen is to offer structural sup- 
port, possibly by providing a surface on which laminin and fibronectin can be deposited. ${ }^{73}$

\section{Maturation of preretinal vessels}

As revealed by fluorescein angiography in a study of PDR, the tips of the actively growing capillaries are unduly permeable due possibly to the presence of interendothelial clefts and short adherent regions. ${ }^{74}$ Although tight encircling junctions have been claimed to form quite early in the proliferation according to an investigation of primates with neovascularisation secondary to experimentally-induced venous stasis $^{14}$ there is some disagreement on the matter. ${ }^{74}$ Analysis of preretinal angiogenesis in rabbits by de Juan et $\mathrm{al}^{75}$ showed that the increased permeability is selective to the extent that whilst fluorescein leakage occurs, larger molecules such as horseradish peroxidase are retained. An initial fenestration has also been described ${ }^{76,77}$ which may be a reflection of the abnormal milieu occasioned by the preretinal situation, ${ }^{78}$ since the converse situation in which normally fenestrated choroidal capillaries lose their fenestrations on crossing Bruch's membrane ${ }^{79}$ suggests that the retina might normally inhibit this development. Fenestrations were rare, however in a study of preretinal membranes in diabetic patients by Williams et al $^{80}$ which implies that they are an unlikely explanation of the persistent increase in permeability. Some other work indicates that the presence of glial tissue may be necessary to induce tight junction formation: ${ }^{81}$ in its absence an effective bloodretinal barrier is not to be expected.

\section{Complications}

As the new vessels mature they commonly acquire a mantle of fibrous tissue, although this may vary considerably in extent. The origin of the fibroblasts in this situation is debatable with identified possibilities including pericyte metaplasia, blood-borne precursors, hyalocytes and, perhaps, particularly when retinal tears are present, the RPE. It has been suggested that the hyperpermeable vessels leak excessive amounts of fluid rich in electrolyte ions which then serve to undermine the protein-glycoaminoglycan linkages essential for the stability of the vitreous gel. ${ }^{82}$

\section{Involution}

In time the fibrovascular proliferation stabilises and the vessels may even undergo spontaneous regression. In experimental situations it has been observed that newly formed capillaries regress once the stimulating factor is withdrawn. ${ }^{83} \mathrm{In}$ part this may be due to thrombosis of the feeder vessel, as has been reported in respect of sickle retinopathy ${ }^{84}$ but atrophy of the underlying retina with reduced metabolic demands may also be involved. As a result of the involutionary process the vessels are reduced to ghost outlines consisting of basement membranes and little else.

\section{In Vitro Studies of Modulatory Influences}

In the absence of a practical animal model with which to study retinal neovascularisation, recent research into the cellular mechanisms of retinal new vessel formation has mainly relied on either in vivo new vessel formation in non-retinal vascular beds (such as corneal pockets ${ }^{85,86}$ or chorioallantoic membrane assays) ${ }^{87}$ or the use of in vitro techniques. Studies of vascular endothelial cell proliferation in vitro have often involved aortic endothelial cells but this is far from ideal since there are important differences between the endothelial cells of large and small blood vessels. ${ }^{88}$ Furthermore, attempts to avoid this problem by using non-retinal microvascular endothelial cells have been frustrated by the observation that even among small vessels there is considerable heterogeneity between different vascular beds. ${ }^{89}$ Differences might also be expected to exist between retinal microvascular endothelial cells of the arterioles and venules since retinal new vessels always originate from the venous side of the retinal vasculature, although in vitro studies suggest that both arteriolar and venular retinal vessels have similar growth characteristics (Rosen unpublished). Despite these difficulties there has been an enormous research effort to understand the underlying mechanisms of new vessel formation.

As already described retinal neovascularisation consists of four major events; (1) basement membrane breakdowns, (2) endothelial cell migration, (3) endothelial cell proliferation, (4) vessel remodelling. ${ }^{18}$

The progress of these various activities is subject to modification by a range of soluble factors, 
some of the more readily identifiable being those which affect endothelial cell proliferation and which are referred to as angiogenic factors.

\section{Angiogenic Factors}

The term "angiogenic" is misleading since the majority of these factors are general mitogens and are not specific for vascular cells. It is possible to subdivide these factors into two groups; those of known origin and those of unknown origin. Perhaps the first truly angiogenic factor for capillary endothelial cells identified was tumour angiogenic factor. ${ }^{90} \mathrm{~A}$ low molecular weight factor (ESAF) similar to that described by Folkman has been identified from bovine and feline retina and has been shown to promote mitosis of both cultured brain and retinal capillary endothelial cells. ${ }^{69}$ This factor may play a major role in angiogenesis since the measured amount of ESAF in the retinae of kittens with vascular proliferation secondary to oxygen induced retinopathy was three times greater that in control animals. ${ }^{91}$ Although the nature of ESAF is not yet known it has been demonstrated in a variety of animal species and tissues and shown to have both mitogenic and migratory properties, as well as the collagenolytic activity referred to earlier. It carries a negative charge ${ }^{45}$ stimulates small but not large vessel endothelium ${ }^{92}$ and requires a collagen substrate to be effective. ${ }^{93}$

\section{Non-specific retinal vascular mitogens}

(i) Extravascular retinal origin.

The culture medium from RPE cells has been shown to stimulate microvascular endothelial cell proliferation ${ }^{94-96}$ (Fig 6). However, this effect is non-specific since this medium can also stimulate the proliferation of astroglial cells, retinal pericytes, Tenon's fibroblasts and even RPE cells themselves. ${ }^{94,97}$ It is likely that this non-specific mitogenic response is due to fibroblast growth factor (FGF), Schweigerer et $\mathrm{al}^{98}$ having demonstrated that RPE cells are a rich source of this factor. A further source of nonspecific mitogenic activity is the neural retina. Extracts of retina are capable of stimulating the proliferation of aortic and retinal microvascular endothelial cells ${ }^{99,100}$ but, once again, this is a non-specific effect since retinal extracts stimulate other ocular and non-ocular cell types (Boulton, unpublished). The retina-derived

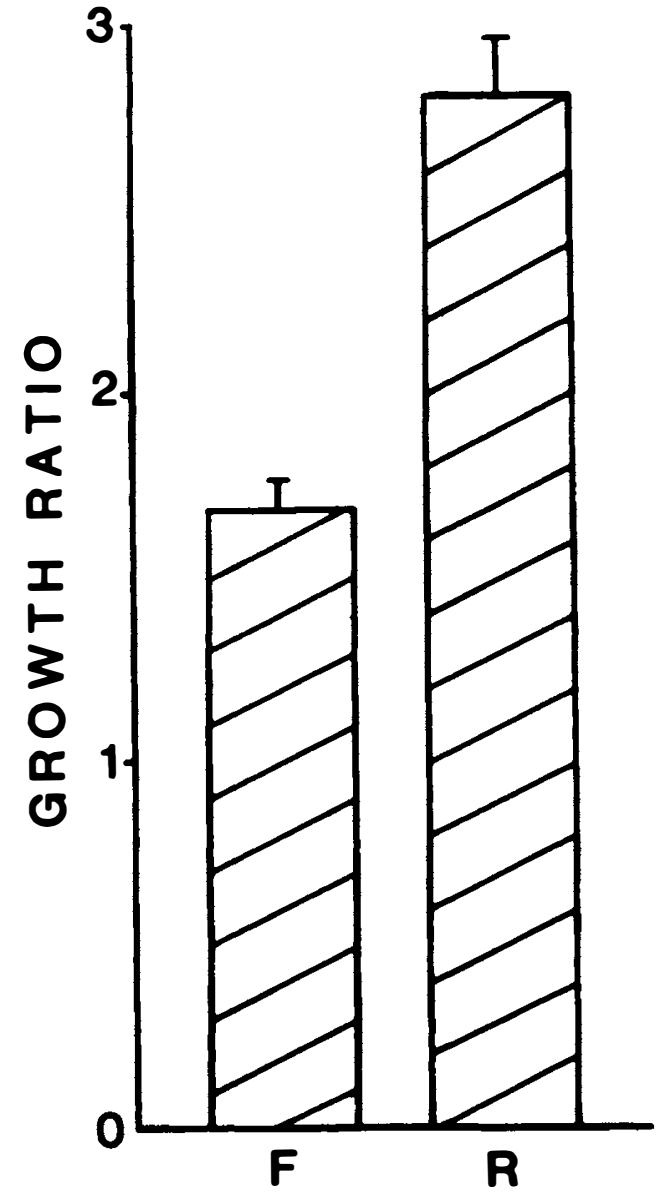

Fig. 6. Comparison of the in vitro effects of $R P E$ conditioned medium $(R)$ and fresh medium $(F)$ on the growth of bovine retinal microvascular endothelial cells. Bar denotes SEM.

growth factor has been purified and characterised $^{101}$ and shown to be similar, if not identical, to FGF. ${ }^{102}$ Using immunohistochemical techniques two species of FGF have been identified in the retina; ${ }^{103,104}$ acidic FGF is located in the ganglion cells, inner nuclear layer, photoreceptor inner segments and extraretinal nerve trunks while basic FGF is found in the microvasculature of the inner nuclear layer. A possible additional source of retina derived non-specific activity are the glial cells. Astroglia from the brain cortex have been shown to stimulate the proliferation of vascular endothelial cells. ${ }^{97}$ Although the mitogenic potential of culture medium from retinal glia to promote vascular endothelial cell proliferation has not been deter- 
mined, retinal glia have been reported to stimulate the proliferation of RPE cells and fibroblasts. ${ }^{105}$

\section{(ii) Retinal vascular origin}

The function of pericytes remains unknown but these cells may have some controlling influence over vessel function. Recent studies have indicated a direct relationship between pericytes and capillary endothelial cells, Wong et al ${ }^{106}$ and Orlidge and D'Amore ${ }^{96}$ having shown that retinal pericytes produce a factor which stimulates proliferation of cultured retinal microvessel endothelial cells. However, this is not a simple matter since, when microvascular endothelial cells are co-cultured with retinal pericytes, their proliferation is inhibited if the pericytes form a direct cell contact with the endothelial cells. ${ }^{96}$ McIntosh et al ${ }^{107}$ have demonstrated that even retinal microvascular endothelial cells are capable of stimulating their own proliferation.

(iii) Others

A plethora of other mitogens have been identified, although not all have yet been adequately defined. Those that have been identified include platelet derived growth factor, epidermal growth factor, insulin, heparin, interleukin, and a number of arachidonic acid derivatives such as the prostaglandins. ${ }^{18,87}$

\section{Extracellular Matrix}

Although we have discussed mitogens in the true sense the importance of extracellular matrix components should not be ignored. There is considerable evidence that angiogenesis is dependent on the substrate available for cell growth. ${ }^{87,108}$ Certainly microvascular endothelial cells in vitro need to attach to either a collagen, gelatin, fibronectin or laminin basement membrane for proliferation and migration to occur. Furthermore, the reactivity of cells to growth factors varies with the substrate on which the cells are grown.

\section{Vitreous}

The normal vitreous has been shown to contain a mixture of both mitogenic and antimitogenic factors. With the exception of FGF which has been identified by radioimmunoassay ${ }^{102}$ the remainder are defined by their molecular weight, heat lability and proteolytic sensitivity. The net mitogenic activity of the vitreous is under debate; embryonic and neonatal vitreous has an overall inhibitory effect while adult vitreous has been purported to be inhibitory. ${ }^{109-112}$ In most studies on adult species the vitreous had been "systematically processed" (including dialysis and column separation) prior to examination. However, some studies using unprocessed vitreous report an overall stimulatory response..$^{38,113}$ The exact source of these molecules is unknown but they are thought to originate from the retina and given the exclusion capacity of the vitreous these may in fact form a concentration gradient. ${ }^{114}$

As previously discussed, Michaelson ${ }^{1}$ hypothesised that non-perfused extravascular retina produces a diffusible angiogenic factor and attempts have been made to identify such factors in the vitreous of patients with PDR. Studies indicate that vitrectomy samples from diabetic eyes have significantly more mitogenic activity than those from non-diseased eyes ${ }^{115}$ (Wong and Boulton, unpublished). Two stimulatory factors have been identified. Baird et al ${ }^{116}$ reported higher than normal levels of FGF in vitrectomy samples from patients with PDR and suggested that FGF may contribute to the neovascular event, while Hill et $\mathrm{al}^{44}$ demonstrated the presence of ESAF.

\section{Photocoagulation and antiangiogenic factors}

The possible existence of inhibitory or antiangiogenic factors has been deduced from the observation that retinal new vessels regress following panretinal photocoagulation. Since the melanin of the RPE is the prime absorber of laser energy it has been postulated that the RPE can in some way modulate new vessels. This matter seemed to be resolved in 1985 when Glaser and colleagues ${ }^{97}$ reported that RPE cells release inhibitors of neovascularisation. In this study RPE- conditioned medium inhibited the mitogenic effect of retinal crude extract on fetal aortic vascular endothelial cells and human retinal microvascular endothelial cells. Part of this inhibitory activity has been identified as transforming growth factor-b (TGF-b), a peptide growth factor capable of inhibiting vascular endothelial cell proliferation. ${ }^{117}$ This contrasts with the subsequent demonstration that RPEconditioned medium stimulates the proliferation of microvascular endothelial cells; $95,96,100$ furthermore, Wong et al ${ }^{118}$ have shown that the 


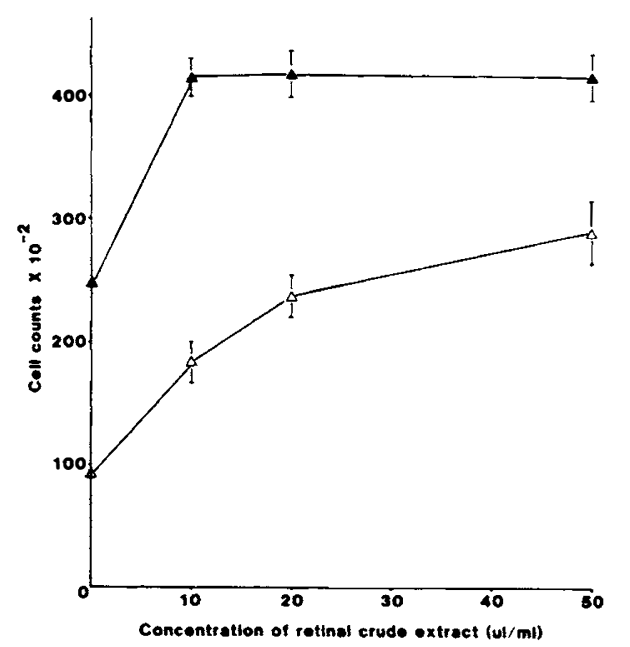

Fig. 7. The mitogenic activity of RPE-conditioned medium enhances the stimulatory effect of retinal crude extract on the proliferation of retinal capillary endothelial cells. ( $\Delta)$ unconditioned medium + varying concentrations of retinal crude extract, $(\Delta)$ $R P E$-conditioned medium + varying concentrations of retinal crude extract. Bar denotes SEM.

mitogenic effect of retinal crude extract is enhanced by RPE conditioned medium (Fig 7).

A more direct approach to the problem has been the measurement of inhibitory factors in the vitreous following panretinal photocoagulation. Two groups have conducted such studies by photocoagulating the retina and have observed inhibitory effects. ${ }^{94,119}$ Boulton et al ${ }^{94}$ showed

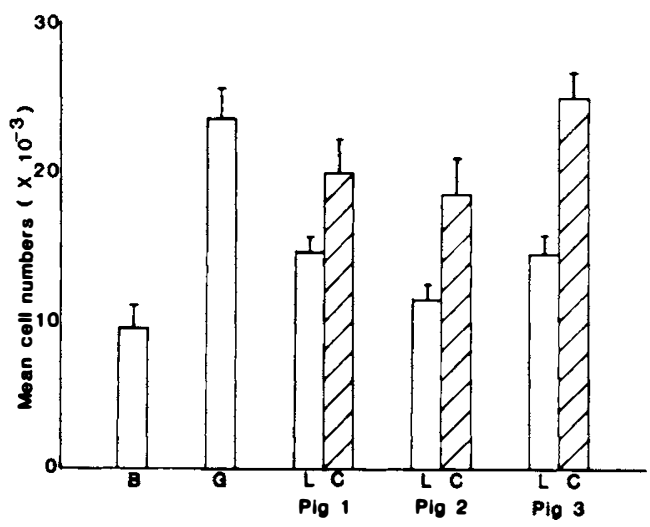

Fig. 8. Comparison of cell counts of bovine retinal microvascular endothelial cells cultured in either basal medium alone $(B)$, growth medium $(G)$, growth medium + lasered vitreous $(L)$ or growth medium + non-lasered vitreous $(C)$. Bar denotes SEM. that vitreous removed four days after panretinal photocoagulation of adult pigs had no effect on the proliferation of bovine retinal microvascular endothelial cells in basal medium but inhibited proliferation in growth medium (Fig 8). Interestingly, while control vitreous was mitogenic for the microvascular cells in basal medium this effect was not observed in growth medium. Glaser et al $^{119}$ demonstrated that an inhibitor of urokinase activity accumulated within the retina two weeks following panretinal photocoagulation of primates. It was suggested that this inhibitor could block tissue invasion early in the process of neovascularisation.

\section{Conclusion}

Experimental studies outlined in the previous sections have concentrated on the cellular mechanisms of retinal new vessel formation but there are other factors, such as inflammatory and systemic influences, which should not be dismissed.

(i) Inflammation - Inflamed tissues are often associated with neovascularisation, particularly in the reparative phase. The proliferative activity associated with inflammation involves macrophages, neutrophils, T-cells, lymphokines, a range of prostaglandins, FGF and probably other factors $^{18}$ as well.

(ii) Systemic factors - Sera from patients with diabetic retinopathy, particularly those with the proliferative form, have been shown to stimulate ${ }^{3} \mathrm{H}$-thymidine incorporation by both large and small vessel endothelial cells. ${ }^{120}$

Although we have discussed a great number of factors that modulate retinal microvascular proliferation it must be remembered that the actions of many growth factors (particularly peptides) include both stimulation and inhibition of cell proliferation. One factor can have both stimulatory and inhibitory activity on a single cell, depending on the context of the other signal molecules present. ${ }^{121}$ A particular example is transforming growth factor-beta (TGF-b) which has been found to both stimulate and inhibit cell growth in a variety of systems. ${ }^{121}$ Recent evidence suggests that TGF-b may have a bifunctional role in regulating neovascularisation. ${ }^{122}$

In summary, the pathogenesis of neovascularisation is highly complex. We have reviewed the proliferative aspects of new vessel formation but 
many of the factors discussed also modulate enzymes involved in basement membrane breakdown and endothelial cell migration. We are therefore no longer dealing with a simple diffusible factor as originally proposed by Michaelson ${ }^{1}$ in 1948 but a large number of factors which together form a balance that maintains the homoeostasis of the retinal vasculature. It is only when this equilibrium is shifted or factors change their activities that new vessel formation is initiated.

\section{References}

${ }^{1}$ Michaelson IC. The mode of development of the vascular system of the retina, with some observations for its significance for certain retinal diseases. Trans Ophthalmol Soc UK 1948; 68: 137-80.

${ }^{2}$ Ashton N. Arteriolar involvement in diabetic retinopathy. Br J Ophthalmol 1953; 37: 282-92.

${ }^{3}$ Ashton N. Studies of the retinal capillaries in relation to diabetic and other retinopathies. $\mathrm{Br} \mathrm{J}$ Ophthalmol 1963; 47: 521-38.

${ }^{4}$ Ashton N. Retinal vascularisation in health and disease. Am J Ophthalmol 1957; 44: 7-20.

${ }^{5}$ Archer DB, Ernest JT, Newell FW. Classification of branch retinal vein obstruction. Trans Am Acad Ophthalmol Otolaryngol 1974; 78: 148-65.

${ }^{6}$ Shilling JS, Kohner EM. New vessel formation in retinal branch vein occlusion. Br J Ophthalmol 1976; 60: 810-15.

${ }^{7}$ Kohner EM, Shilling JS, Hamilton AM. The role of avascular retina in new vessel formation. Metab Ophthalmol 1976; 1: 15-23.

${ }^{8}$ Shimizu K, Kobayashi Y, Muraoka K. Midperipheral fundus involvement in diabetic retinopathy. Ophthalmol 1981; 88: 601-12.

${ }^{9}$ Wise GN. Retinal neovascularisation. Trans $A m$ Acad Ophthalmol Otolaryngol 1956; 54: 729-826.

${ }^{10}$ Patz A. Clinical and experimental studies on retinal neovascularisation. Am J Ophthalmol 1982; 94: 715-43.

"Henkind P. Ocular neovascularisation. Am J Ophthalmol 1978; 85: 287-301.

${ }^{12}$ Neupert JR, Brubaker RF, Kearns TP, Sundt TH. Rapid resolution of venous stasis retinopathy after carotid endarterectomy. Am J Ophthalmol 1976; 81: 600-2.

${ }^{13}$ McLeod D. Reappraisal of the retinal cotton-wool spot: a discussion paper. J Roy Soc Med 1981; 74: 682-6.

${ }^{14}$ Archer DB. Retinal neovascularisation. Trans Ophthalmol Soc UK 1983; 103: 2-27.

${ }^{15}$ Finkelstein D, Clarkson J, Diddie K, Hillis A, Kimball A, Orth D, Trempe C. Branch vein occlusion: retinal neovascularisation outside the involved segment. Ophthalmol 1982; 89: 1357-61.

${ }^{16}$ Magargal LE, Brown GC, Augsburger JA, Parrish R. Neovascular glaucoma following central retinal vein obstruction. Ophthalmol 1981; 88: 1095-101.

${ }^{17}$ Forrester JV, Wilkinson PC. Inhibition of leucocyte locomotion by hyaluronic acid. J Cell Sci 1981; 48: $315-31$.

${ }^{18}$ Garner A. Ocular angiogenesis. Int Rev Exp Pathol 1986; 28: 249-306.

${ }^{19}$ Mandelcorn MS, Blankenship G, Machemer R. Pars plana vitrectomy for the management of severe diabetic retinopathy. Am J Ophthalmol 1976; 81: 561-70.

${ }^{20}$ Michels RG. Vitrectomy for complications of diabetic retinopathy. Arch Ophthalmol 1978; 96: 237-46.

${ }^{21}$ Charles S. Vitreous Microsurgery, 2nd ed. Baltimore, London, Williams \& Wilkins, 1987.

${ }^{22}$ Rice TA, Michels RG, Maguire MG, Rice EF. The effect of lensectomy on the incidence of iris neovascularisation and neovascular glaucoma after vitrectomy for diabetic retinopathy. $A m J$ Ophthalmol 1983; 95: 1-11.

${ }^{23}$ Trempe CL, Takahashi M, Topilow HW. Vitreous changes in retinal branch vein occlusion. Ophthalmol 1981; 88: 681-7.

${ }^{24}$ Wong HC, Sehmi KS, McLeod D. Abortive neovascular outgrowths discovered during vitrectomy for diabetic vitreous haemorrhage. (In press).

${ }^{25}$ Chan CC, Little HL. Infrequency of retinal neovascularisation following central retinal vein occlusion. Ophthalmol 1979; 86: 256-62.

${ }^{26}$ Ashton N, Cook C. Studies of developing retinal vessels. I. Influence of retinal detachment. $\mathrm{Br} \mathrm{J}$ Ophthalmol 1955; 39: 449-56.

${ }^{27}$ McLeod D. Silicone oil injection during closed microsurgery for diabetic retinal detachment. Graefes Arch Klin Exp Ophthalmol 1986; 224: 55-9.

${ }^{28}$ Yeo JH, Glaser BM, Michels RG. Silicone oil in the treatment of complicated retinal detachments. Ophthalmol 1987; 94: 1109-13.

${ }^{29}$ McLeod D, James CRH. Viscodelamination at the vitreoretinal juncture in severe diabetic eye disease. Br J Ophthalmol 1988; 72: 413-19.

${ }^{30}$ Hercules BL, Gayed II, Lucas SB, Jeacock J. Peripheral retinal ablation in the treatment of diabetic retinopathy: a three-year interim report of a randomised, controlled study using the argon laser. Br J Ophthalmol 1977; 61: 555-63.

${ }^{31}$ Diabetic Retinopathy Study Research Group. Photocoagulation treatment of proliferative diabetic retinopathy: clinical application of DRS findings. Ophthalmol 1981; 88: 583-600. 
${ }^{32}$ Branch Vein Occlusion Study Group. Argon laser scatter photocoagulation for prevention of neovascularisation and vitreous haemorrhage in branch vein occlusion. Arch Ophthalmol 1986; 104: $34-41$.

${ }^{33}$ May DR, Klein ML, Peyman GA, Raichand M. Xenon-arc panretinal photocoagulation for central retinal vein occlusion: a randomised prospective study. $\mathrm{Br} J$ Ophthalmol 1979; 63: 725-34.

${ }^{34}$ Ficker LA, Passani F, Leaver PK, McLeod D. Xenon-arc endophotocoagulation during vitrectimy for diabetic vitreous haemorrhage. Graefes Arch Klin Exp Ophthalmol 1986; 224: 423-7.

${ }^{35}$ Wolbarsht ML, Landers MB. The rationale of photocoagulation therapy for proliferative diabetic retinopathy: a review and a model. Ophthal Surg 1980; 11: 235-45.

${ }^{36}$ Foulds WS. The role of photocoagulation in the treatment of retinal disease. Trans Ophthalmol Soc NZ 1980; 32: 82.

${ }^{37}$ Glaser BM, Campochiaro PA, Davis JL, Jerdan JA. Retinal pigment epithelial cells release inhibitors of neovascularisation. Ophthalmol 1987; 94: 780-4.

${ }^{38}$ Boulton M, Lane C, Singh A, Wong HC, Bridgman A, McLeod D, Marshall J. Effects of vitreous from photocoagulated eyes on retinal microvascular cells in culture: a preliminary report. Curr Eye Res 1988; 7: 465-70.

${ }^{39}$ Cliff WJ. Observations on healing tissue: a combined light and electron microscopic investigation. Philos Trans $R$ Soc 1963; 246: 305-25.

${ }^{40}$ Klintworth GK. The hamster cheek pouch: an experimental model of corneal vascularisation. Am J Pathol 1973; 73: 691-710.

${ }^{41}$ Ishibashi T, Miller H, Orr G, Sorgente N, Ryan SJ. Morphologic observations on experimental subretinal neovascularisation in the monkey. Invest Ophthalmol Vis Sci 1987; 28: 1116-30.

${ }^{42}$ Rifkin DB, Gross JL, Moscatelli D, Jaffe E. Proteases and angiogenesis: production of plasminogen activator and collagenase by endothelial cells. In Nossel HL, Vogel HJ eds. 'Pathobiology of the endothelial cell' New York: Academic Press 1982: 191-97.

${ }^{43}$ Weiss JB, Hill CR, Davis RJ, McLaughlin B, Sedowofia KA, Brown RA. Activation of procollagenase by low molecular angiogenesis factor. Biosci Rep 1983; 3: 171-7.

${ }^{44}$ Hill CR, Kissun RD, Weiss JB, Garner A. Angiogenic factor in vitreous from diabetic retinopathy. Experientia 1983; 39; 583-5.

${ }^{45}$ Weiss JB, Brown RA, Kumar S, Phillips P. Tumour angiogenesis factor: a potent low molecular weight compound. Br J Cancer 1979; 40: 493-6.
${ }^{46}$ Weiss JB, Hill CR, Schor A. Low-molecular-mass tumour angiogenesis factor. Biochem Soc Trans 1984; 12: 260.

${ }^{47}$ Kalebic T, Garbisa S, Glaser B, Liotta LA. Basement membrane collagen: degradation by migrating endothelial cells. Science 1983; 221: 281-3.

${ }^{48}$ Ausprunk DH, Folkman J. Migration and proliferation of endothelial cells in preformed and newly formed blood vessels during tumour angiogenesis. Microvasc Res 1977; 14: 53-65.

${ }^{49}$ Folkman J, Haudenschild C. Angiogenesis in vitro. Nature 1980; 228: 551-6.

${ }^{50}$ Glaser BM, Kuwashima L, Sato M, Adler R. The formation and maintenance of new blood vessels. In BenEzra D, Ryan SJ, Glaser BM, Murphy RP, eds. 'Ocular Circulation'. Dordrecht: Martinus Nijhoff/W. Junk 1987: 77-83.

${ }^{51}$ Ishibashi T, Miller H, Orr G, Sorgente N, Ryan SJ. Mechanisms of lumen formation: morphologic observations on experimental subretinal neovascularisation. In BenEzra D, Ryan SJ, Glaser BM, Murphy RP, eds. 'Ocular Circulation'. Dordrecht: Martinus Nijhoff/W. Junk 1987: 437-443.

${ }^{52}$ Frank RN, Mancini MA. Presumed retinovitreal neovascularisation in dystrophic retinas of spontaneously hypertensive rats. Invest Ophthalmol Vis Sci 1986; 27: 346-55.

${ }^{53}$ Glaser BM. Future trends and concepts. In BenEzra D, Ryan SJ, Glaser BM, Murphy RP. eds 'Ocular Circulation and Neovascularization' Dordrecht: Martinus Nijhoff/W. Junk 1987: 565-567.

${ }^{54}$ Kohno T, Sorgente N, Goodnight R, Ryan SJ. Alterations in the distribution of fibronectin and laminin in the diabetic human eye. Invest Ophthalmol Vis Sci 1987; 28: 515-21.

${ }^{55}$ Ashton N. Diabetic micro-angiopathy. $A d v$ Ophthalmol 1958; 8 (bibl Ophthalmol Fasc 52): 1-84.

${ }^{56}$ Garner A. Retinal angiogenesis: mechanism in health and disease. Semin Ophthalmol 1987; 2: 71-80.

${ }^{57}$ Hamilton AM, Marshall J, Kohner EM, Bowbyes JA. Retinal new vessel formation following experimental venous occlusion. Exp Eye Res 1975; 20: 493-7.

${ }^{58}$ Ashton N, Ward B, Serpell G. Effect of oxygen on developing retinal vessels with particular reference to the problem of retrolental fibroplasia. Br J Ophthalmol 1954; 38: 397-432.

${ }^{59}$ Ashton N. Oxygen and the growth and development of retinal vessels: in vivo and in vitro studies. Am J Ophthalmol 1966; 62: 412-35.

${ }^{60}$ Foos RY, Kopelow SM. Development of retinal vasculature in perinatal infants. Surv Ophthalmol 1973; 18: 117-27. 
${ }^{61}$ Kushner BJ, Essner D, Cohen IJ, Flynn JT. Retrolental fibroplasia: pathologic correlation. Arch Ophthalmol 1977; 95: 29-38.

${ }^{62}$ Serpell G. Polysaccharide granules in association with developing retinal vessels and with RLF. $\mathrm{Br}$ J Ophthalmol 1854; 38: 460-71.

${ }^{63}$ Ashton N. Retinal angiogenesis in the human embryo. Br Med Bull 1970; 26: 103-6.

${ }^{64}$ Flower RW, McLeod DS, Lutty GA, Goldberg B, Wajer SD. Postnatal retinal vascular development of the puppy. Invest Ophthalmol Vis Sci 1985; 26: 957-68.

${ }^{65}$ Cogan DG, Kuwabara T. Accessory cells in vessels of the paranatal human retina. Arch Ophthalmol 1986; 104: 747-52.

${ }^{66}$ Nork TM, Wallow IHL, Kramer SJ, Anderson G. Muller cell involvement in proliferative diabetic retinopathy. Arch Ophthalmol 1987; 105: 1424-9.

${ }^{67}$ Foos RY. Acute retrolental fibroplasia. Albrecht Graefes Arch Ophthalmol 1975; 195: 87-100.

${ }^{68}$ Kretzer FL, Hittner HM. Initiating events in the development of retinopathy of prematurity. In Silverman WA, Flynn JT eds. 'Contemporary Issues in Fetal and Neonatal Medicine: 2. Retinopathy of Prematurity'. Boston, Oxford: Blackwell 1986: 121-152.

${ }^{69}$ Elstow SF, Schor AM, Weiss JB. Bovine retinal angiogenesis factor is a small molecule (molecular mass <600). Invest Ophthalmol Vis Sci 1985; 26: 74-9.

${ }^{70}$ Montesano R, Orci L, Vassalli P. In vitro rapid organization of endothelial cells into capillarylike networks is promoted by collagen matrices. J Cell Biol 1983; 97: 1648-52.

${ }^{71}$ Frank RN. Basement membranes and retinal neovascularization. In BenEzra D, Ryan SJ, Glaser BM, Murphy RP, eds 'Ocular Circulation and Neovascularization'. Dordrecht: Martinus Nijhoff/W. Junk 1987: 393-400.

${ }^{72}$ Kennedy A, Mancini MA, Frank RN. A type 1 collagen substrate stimulates cultured retinal cells to produce insoluble proteoglycan. Invest Ophthalmol Vis Sci 1986; 27 (Suppl): 327.

73 Jerdan JA, Glaser BM. The extracellular matrix of the human retinal vasculature. Invest Ophthalmol Vis Sci 1984; 25 (Suppl): 247.

${ }^{74}$ Miller H, Miller B, Zonis S, Nir I. Diabetic neovascularization; permeability and ultrastructure. Invest Ophthalmol Vis Sci 1984; 25: 1338-42.

75 Juan E de, Wilson D, Hatchell D. Breakdown of the blood-retinal barrier in a model of retinal neovascularization. Invest Ophthalmol Vis Sci 1987; 28: 1108-15.

76 Taniguchi Y. Ultrastructure of newly formed blood vessels in diabetic retinopathy. Jap J Ophthalmol 1976; 20: 19-28.
${ }^{77}$ Wallow IHL, Geldner PS. Endothelial fenestrae in proliferative diabetic retinopathy. Invest Ophthalmol Vis Sci 1980; 19: 1176-83.

${ }^{78}$ Korte GE, Bellhorn RW, Burns MS. Urethane induced rat retinopathy: plasticity of the bloodretinal barrier in disease. Invest Ophthalmol Vis Sci. 1986; 25: 1027-34.

${ }^{79}$ Grindle CFJ, Marshall J. Aging changes in Bruch's membrane and their functional implications. Trans Ophthalmol Soc UK 1978; 98: 172-5.

${ }^{80}$ Williams JM, Juan E de, Machemer R. Ultrastructural characteristics of new vessels in proliferative diabetic retinopathy. $A m \quad J$ Ophthalmol 1988; 105: 491-5.

${ }^{81}$ Janzer RC, Raff MC. Astrocytes induce bloodbrain barrier properties in endothelial cells. Nature 1987; 325: 253-7.

${ }^{82}$ Constable IJ. Pathology of vitreous membranes and the effect of haemorrhage and new vessels on the vitreous. Trans Ophthalmol Soc UK 1975; 95: 382-6.

${ }^{83}$ Ausprunk DH, Falterman K, Folkman J. The sequence of events in the regression of corneal capillaries. Lab Invest 1978; 38: 284-94.

${ }^{84}$ Nagpal KC, Patrianokos D, Asdourian GK, Goldberg MF, Rabb MF, Jampol L. Spontaneous regression (autoinfarction) of proliferative sickle retinopathy. Am J Ophthalmol 1975; 80: 885-92.

${ }^{85}$ Klintworth GK, Burger PC. Neovascularisation of the cornea: current concepts. of its pathogenesis. Int Ophthalmol Clin. 1983; 23: 27-33.

${ }^{86}$ BenEzra D, Hemo I, Maftzir G. The rabbit cornea - a model for the study of angiogenic factors. In Ocular Circulation and Neovascularisation (Ed BenEzra D, Ryan SJ, Glaser BM, Murphy RP), 1987; Martinus Nijhoff/Dr W Junk Publishers, pp335-340.

${ }^{87}$ Hudlicka O, Tyler KR. Angiogenesis: The growth of the vascular system. Academic Press 1986.

${ }^{88}$ Zetter BR: The endothelial cells of large and small vessels. Diabetes. 1981; 30: 24-8.

${ }^{89}$ Auerbach R, Kaminska G, Weber J, Gumkowski F, Kaminski M, Morrissey LW, Bielich J, Woods V, Lu WC, Kubai L. Heterogeneity of vascular endothelial cells: its possible role in selective neovascularisation in the eye. In Ocular Circulation and Neovascularisation (Ed BenEzra D, Ryan SJ, Glaser BM, Murphy RP), 1987; Martinus Nijhoff/Dr W Junk Publishers, pp 361-365.

${ }^{90}$ Folkman J, Merler E, Abernathy C, Williams C. Isolation of a tumor factor responsible for angiogenesis. J Exp Med. 1971; 133: 275-88.

${ }^{91}$ Taylor CM, Weiss JB, Kissun RD, Garner A. Effect of oxygen tension on the quantities of procollagenase-activating angiogenic factor present in the developing kitten retina. $\mathrm{Br} J$ Ophthalmol. 1986; 70: 162-5. 
92 Schor AM, Schor SL, Weiss JB, Brown RA, Kumar S, Phillips P. Stimulation by a lowmolecular weight angiogenic factor of capillary endothelial cells in culture. Br J Cancer 1980; 41: 790-9.

${ }^{93}$ Schor AM, Schor SL, Kumar S. Importance of a collagen substratum for the stimulation of capillary endothelial cell stimulation by tumour angiogenesis factor. Int $J$ Cancer 1979; 24: 225-34.

${ }^{94}$ Boulton M, Wong HC, Clark P, Marshall J. A mitogenic factor or factors produced by cultured human retinal pigment epithelial cells. In Ocular Circulation and Neovascularisation (Ed BenEzra D, Ryan SJ, Glaser BM, Murphy RP), 1987; Martinus Nijhoff/Dr W Junk Publishers, pp 529-534

${ }^{95}$ Morse LS, Sidikaro Y, Terrell J. Retinal pigment epithelium promotes proliferation of choroidal vessels in vitro. Invest Ophthalmol Vis Sci 1986; 27 (Suppl): 327.

96 Orlidge A, D'Amore P. Inhibition of capillary endothelial cell growth by pericytes and smooth muscle cells. J Cell Biol 1987; 105: 1455-62.

${ }^{97}$ Glaser BM, Campochiaro PA, Davis JL, Sato M. Retinal pigment epithelial cells release an inhibitor of neovascularisation. Arch Ophthalmol 1985; 103: 1870-5.

98 Schweigerer L, Malerstein B, Neufeld G, Gospodarowicz D. Basic fibroblast growth factor is synthesised in cultured retinal pigment epithelial cells. Biochem. Biophys. Res. Comm. 1987; 143: 934-42.

99 Glaser BM, D’Amore PA, Michels RG, Patz A, Fenselau A. Demonstration of vasoproliferative activity from mammalian retina. J Cell Biol 1980; 84: 298-30.

${ }^{100}$ Wong HC, Boulton ME, Clark P, Bayly M, Marshall J. Retinal pigment epithelial cells produce mitogenic factors for retinal microvascular cells in culture: A preliminary report. Eye 1987; 1: 754-6.

${ }^{101}$ D'Amore P, Klagsbrun M. Endothelial cell mitogens derived from retina and hypothalmus: biochemical and biological similarities. J Cell Biol 1984; 99: 1545-9.

102 Baird A, Esch F, Gospodarowicz D, Guillemin R. Retina- and eye-derived endothelial cell growth factor: partial molecular characterisation and identity with acidic and basic growth factors. Biochem. 1985; 24: 7855-60.

${ }^{103}$ Hanneken A, McLeod DS, Lutty G, Hjelmeland LM: Non-coincident localization of acidic and basic FGF in fetal bovine retina. Invest Ophthalmol Vis Sci 1987; 28 (Suppl): 259.

${ }^{104}$ Hanneken A, Lutty G, Hjelmeland LM. Localization of basic FGF in normal and diabetic human retinas. Invest Ophthalmol Vis Sci 1988; 29 (Suppl): 182.

${ }^{105}$ Burke JM, Foster SJ. Induction of DNA synthesis by co-culture of retinal glia and pigment epithelium. Invest Ophthalmol Vis Sci 1985; 26: 636-42.

${ }^{106}$ Wong HC, Boulton M, Marshall J, Clark P. Growth of retinal capillary endothelia using pericyte conditioned medium. Invest Ophthalmol Vis Sci 1987; 28: 1767-75.

${ }^{107}$ McIntosh LC, Muckersie L, Forrester JV. Retinal capillary endothelial cells prefer different substrates for growth and migration. Tissue Cell 1988; 20: 193-209.

${ }^{108}$ Gospodarowicz D, Vlodavsky I, Savion N. The extracellular matrix and the control of proliferation of vascular endothelial and vascular smooth muscle cells. J Supramol Struct 1982; 13: 339-72.

${ }^{109}$ Brem S, Preis I, Langer R, Brem H, Folkman J, Patz A. Inhibition of neovascularisation by an extract derived from vitreous. Am J Ophthalmol 1977; 84: 323-8.

110 Jacobson B, Basu PK, Hasany SM. Vascular endothelial cell growth inhibitor of normal pathologic vitreous. Arch Ophthalmol 1984; 102: 1543-5.

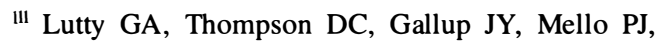
Patz A, Fenselau A. Vitreous: An inhibitor of retinal extract induced neovascularisation. Invest Ophthalmol Vis Sci 1983; 23: 52-6.

112 Lutty GA, Mello R, Chandler C, Fait C, Bennett A, Patz A. Regulation of cell growth by vitreous humour. J Cell Sci 1985; 76: 53-65.

${ }^{113}$ Chen C-H, Chen SC. Angiogenic activity of the vitreous and retinal extract. Invest Ophthalmol Vis Sci 1980; 19: 596-602.

${ }^{114}$ Balazs EA, Denlinger JL. The vitreous. In The Eye (Ed Davson H) 1984; Academic Press, pp 533-590.

115 Lutty GA, Chandler C, Bennett A, Fait C, Patz A. Presence of endothelial cell growth factor activity in normal and diabetic eyes. Curr Eye Res 1986; 5: 9-17.

${ }^{116}$ Baird A, Coller F, Jones K, Guillemin R. Angiogenic factor in human ocular fluids. Lancet 1985; ii 563.

${ }^{117}$ Connor T, Roberts A, Sporn M, Davis J, Glaser B. RPE cells synthesise and release transforming growth factor-beta, a modulator of endothelial cell growth. Invest Ophthalmol Vis Sci 1988; 29 (Suppl): 307.

118 Wong HC, Boulton M, McLeod D, Bayly M, Clark P, Marshall J. Retinal pigment epithelial cells in culture produce retinal vascular mitogens. Arch Ophthalmol 1988; (in press).

${ }^{119}$ Glaser BM. Extracellular modulating factors and 
the control of intraocular neovascularisation: an overview. Arch Ophthalmol 1988; 106: 603-7.

${ }^{120}$ Petty RG, Pearson JD, Morgan DM, Mahler RF. Stimulation of endothelial cell growth by sera from diabetic patients with retinopathy. Lancet 1988; i: 208-11.

${ }^{121}$ Sporn MB, Roberts AB, Peptide growth factor are multifunctional. Nature 1988; 332: 217-19.

122 Glaser BM, Hayashi H, Krause WG. A protease inhibitor accumulates within the vitreous following pan retinal photocoagulation (PRP) in primates: possible mechanisms for the effect of PRP on retinal neovascularisation. Invest Ophthalmol Vis Sci 1988; 29 (Suppl): 180. 